\title{
Science returns to Einstein's rural retreat
}

[MUNICH] A six-year dispute over the ownership of Einstein's summer house in east Germany appears to have been resolved to the benefit of science.

The Amt zur Regelung offener Vermögensfragen (ARV), the German office which establishes ownership of property confiscated by the Nazis, has ruled that the house should be given to Einstein's descendants.

This means it will almost certainly be preserved exclusively for scholarly activities, and no longer be used as a tourist attraction. It reverses the ARV's 1992 decision to give ownership to the tourist-hungry village of Caputh, where the house is located though Caputh is planning to appeal, and objections from some beneficiaries about the rights of others to be considered heirs could still be lodged.

The wooden house, tucked in the forests of Brandenburg, has had a dismal history. Einstein spent only three summers there before leaving Germany permanently in 1933 when the Nazis rose to power. In 1935 Einstein was declared an enemy of the state and his properties were confiscated. The ownership of the summer house was transferred to the village of Caputh for DM5,000, a fraction of the price that Einstein had paid to build it. However, the village has not been able to prove that it actually paid the money.

Caputh initially used the house as a Jewish orphanage, but the children were driven out to die in the forests in 1938. Next, it was used as a camp by Nazi youth groups. After the war it was used to shelter refugees. It then fell into disrepair, but east German physicists persuaded the science ministry to renovate it in 1979 for Einstein's centenary. Thereafter it was used as a guest house for scholars by the DDR Academy of Sciences.

When the academy was dissolved after reunification, the house, now a protected historical monument, was entrusted to the state of Brandenburg until rightful ownership could be established. Hoping to continue the house's academic associations, Brandenburg set up the Einstein Forum, which it hoped could establish a series of scientific workshops and seminars there.

But the plan went awry when in 1992 the ARV declared Caputh the rightful owner, agreeing that the village had bought it legally in the 1930s. This decision was disputed by Einstein's heirs and the forum, who feared using it as a tourist attraction would endanger its fragile structure. The village made an agreement with Brandenburg and the Einstein Forum to restrict guided tours to weekends, in exchange for much-needed financial help. On top of standard running costs, there is an annual bill of DM140,000 for roundthe-clock security services: the house was declared a 'politically endangered site' by the

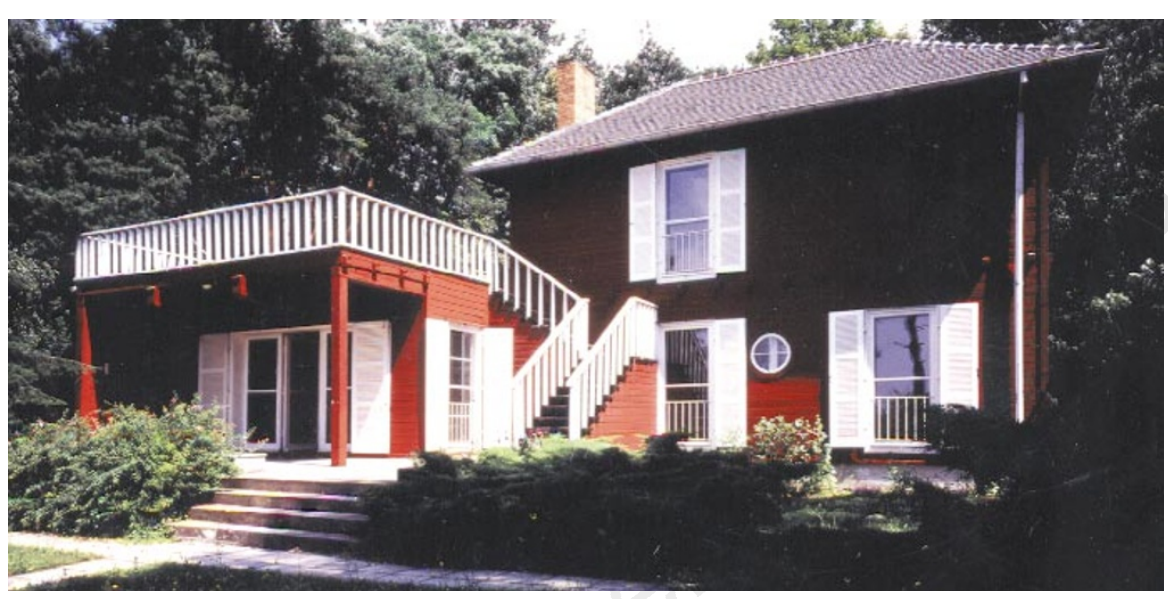

Domestic science: tourism will make way for scholarly pursuits at Einstein's old summer house.

Brandenburg government after neo-nazis firebombed some properties in the area.

The forum is now trying to raise some DM2 million (US\$1.12 million) to buy the house from the 12 named beneficiaries, who are willing to sell, provided the house is used for scholarly purposes. One, the Hebrew University in Jerusalem, agreed to transfer its rights to the Einstein Forum. But Gary Smith, president of the forum, is not prepared to guess when the house will find lasting peace. "Six years ago I predicted the issue would be resolved within half a year," he says, "so I won't be drawn on making predictions again."

Smith is keen to see the issue resolved quickly. The dispute has discouraged Caputh from investing in the house, which is falling once again into disrepair.

Alison Abbott

\section{Crop trials speed up as eco-warriors strike}

[LONDON] The British government, farmers, and the biotechnology industry are considering how to respond to destruction of genetically modified crop trials by 'eco-warrior' environmentalist groups.

Possible options include greater security around trial sites; carrying out trials in closed, company-owned locations, rather than fields owned by farmers; and simply not publicizing their specific location in a field.

Concern is mounting following an incident last week when protesters destroyed a crop of genetically modified maize in Devon, causing losses of $\mathfrak{E} 600,000$ (US\$978,000). The crop was being assessed for a commercial seed listing, having passed safety tests.

The trial was at the centre of an unsuccessful court challenge by a coalition of groups including a nearby farmer and Friends of the Earth. They wanted it stopped, partly out of concern that it might pollinate a nearby crop of organic sweetcorn (see Nature 394, 212; 1998).

John McLeod, director of the National Institute for Agricultural Botany (NIAB), which was carrying out the Devon maize trial, is opposed to carrying out trials behind closed doors. He says they need to be carried out in open environments, particularly where pollination is being measured.

But while he remains committed to openness and transparency, McLeod says he is now beginning to have reservations about publiciz- ing the specific location of genetically modified trials. The law requires the government to publicize the location of a crop trial. However, there is no requirement to make the exact field grid reference public knowledge.

Government sources say they have considered changing their current practice of making specific crop sites public knowledge.

But the sources, as well as the company which was developing the Devon maize, Sharpes International Seeds, say this would be a retrograde step. "Having been so open now, we can't possibly go back," says a government official.

The Devon destruction is the latest in a string of incidents involving a new and relatively unknown group by the name of GenetiX Snowball, comprising environmental activists and local residents opposed to genetic modification in agriculture.

In the meantime, the Ministry of Agriculture, Fisheries and Food is to speed up the seed certification process by waiving the requirement on companies to show results of two of their own seed trials before submitting seed for a government-monitored trial.

A ministry spokesman said that this did not have implications for safety, which would already have been assessed by the Department of the Environment before any seed was passed onto the agriculture ministry for certification. Ehsan Masood \& Katherine Akingbade 